\title{
The Compost of Olive Mill Pomace: From a Waste to a Resource - Environmental Benefits of Its Application in Olive Oil Groves
}

\author{
Beatriz Gómez-Muñoz, David J. Hatch, Roland Bol and Roberto García-Ruiz
}

Additional information is available at the end of the chapter

http://dx.doi.org/10.5772/48244

\section{Introduction}

Olive oil farming is a significant feature of land use in Mediterranean regions, covering over five million hectares in the EU Member States. The main areas of olive oil production are in Spain (2.4 million ha), followed by Italy (1.4 million ha), Greece (1 million ha) and Portugal (0.5 million ha) [1]. Whilst olive plantations are found over most of the Mediterranean region, around $65 \%$ of the Spanish olive oil area is located in Andalusia (southern Spain), representing $30 \%$ of the total EU olive oil production and about $35 \%$ of the utilized agricultural area. Therefore, olive oil farming in Andalusia is of great social, economic and environmental significance and any change in the olive oil industry in terms of management practices and post-processing options could be of wide importance, at least at the regional scale.

The olive oil industry generates large quantities of by-products. Almost all of the olive mills in Spain use the two-phase centrifugation system for oil extraction to reduce wastewater generation and lower the contaminant load, compared with the three-phase centrifugation system [2] which is currently used by other Mediterranean countries. The main by-product of the two-phase extraction system is olive mill pomace (OMP, hereafter), which in Mediterranean areas is produced during a short period over the winter, from November to February [3], the amount generated varying between 7 and 30 million $\mathrm{m}^{3}$ per year [4-6]. Typically, OMP is a semi-solid to semi-liquid by-product resulting from the mix of "alpechin", the main by-products resulting from the older three-phase extraction procedure, and "orujo". This by-product is made mainly with water, seed and pulp and is a potentially harmful by-product for the environment, because of the phytotoxic and antimicrobial properties, low $\mathrm{pH}$, relatively high salinity and organic load, and the phenolic 
and lipid constituents [7-11]. Direct application to rivers or soil is not allowed under most of the national regulations of the producer countries. The main physico-chemical characterization of OMP can be found in other reports $[10,12,13]$. According to these studies, $\mathrm{OMP}$ is acidic, with a very high content of organic matter and carbon, rich in potassium $(\mathrm{K})$, poor in phosphorus $(\mathrm{P})$, with intermediate levels of nitrogen $(\mathrm{N})$ and may also contain phenolic and lipid compounds.

Some economic (due to costs associated with disposal) and environmental problems arise from the disposal of OMP. The various options for the fate of the large amounts of OMP which are produced annually in Andalusia can be very diverse: a general description of these can be found in [14]. Briefly, one alternative for the disposal of this large amount of OMP could be in evaporative ponds, but large areas would be required for this option which might also pose several potential environmental problems such as bad odour, leaching and insect proliferation. Another major preferred option would include the generation of renewable energy taking advantage of the relatively high calorific value of OMP. Other important uses include the transformation of OMP into an organic fertiliser and soil conditioner through composting. The process of composting OMP consists of mixing it with a blend of natural organic residues (e.g. olive leaves and twigs collected after cleaning the olive fruit in the mill, and/or straw, or manures), which is then allowed to decompose in aerated piles for 7 to 9 months. This means of re-utilization can help to improve soil fertility in olive oil farms which are characterized by low organic matter, reduce the cost of inorganic fertilisers or, for a commercial enterprise, can provide an additional source of revenue for the olive oil mill economy. The main reasons for composting are that OMP has a semi-solid consistency which makes it difficult to manage, and to eliminate any phytotoxical effects by composting for at least 18 weeks [15]. Composting OMP enables it to be sanitized; the mass and volume of the product are reduced and stabilized prior to land spreading. As already mentioned, before composting, OMP is mixed with bulking agents such as olive tree leaves, which are gathered along with the olive fruit, twigs and small branches, straw [16], cotton waste [17] and manure to increase the nutrient content, or any other materials of animal or plant origin which are available locally.

In Andalusia, composted olive mill pomace (COMP, hereafter) production has increased exponentially during the last seven years from 1000 tonnes in 2003 to 70000 in 2011 [18] and there are about 14 olive mills which are producing COMP in this region. Despite this rapid increase, there are no published studies on the main agrochemical properties and the effects of OMP application to soil. Indeed, there are few studies on the main physico-chemical changes in OMP during composting [19-21], or on the chemical characterisation of the final OMP composted product [22]. Moreover, these studies have been undertaken using only a limited number of OMP composts, which were produced in only low experimental quantities and at a small experimental scale. The main aims of this chapter are to review the information from other studies and our own on the agrochemical characterization of COMP currently produced in Andalusia and on the short- and long-term effects of its application on the soil physico-chemical and biological properties. 


\section{Agrochemical characterization of composted olive mill pomace}

The relatively high diversity of the bulking agents used (such as olive mill pomace, olive leafy material (OLM), manure or straw) as well as the variable proportion in which they are mixed is responsible for the highly heterogeneous nature and variability of the quality of the COMP.

\subsection{Composition of commercially produced composted olive mill pomace}

As far as we know, there are no studies on the characterization of currently commercially produced COMP. In one of our own study, seven ready to apply OMP composts were collected from different olive mills located in several provinces of Andalusia. COMP samples differed in composition and in the proportions of primary materials such as OMP, OLM, manure and straw, as shown in Table 1 and Picture 1.

\begin{tabular}{|c|c|c|c|c|}
\hline $\begin{array}{l}\text { Composted olive } \\
\text { mill pomace }\end{array}$ & OMP & OLM & Manure & Straw \\
\hline COMP1 & $80 \%$ & $7 \%$ & Sheep M 13\% & \\
\hline COMP2 & $75 \%$ & $12 \%$ & Poultry M 13\% & \\
\hline COMP3 & $60 \%$ & & Sheep M 40\% & \\
\hline COMP4 & $70 \%$ & $8 \%$ & Sheep M 12\% & $10 \%$ \\
\hline COMP5 & $85 \%$ & $5 \%$ & & $10 \%$ \\
\hline COMP6 & $80 \%$ & $20 \%$ & & \\
\hline COMP7 & $80 \%$ & $13 \%$ & Poultry M 7\% & \\
\hline
\end{tabular}

Table 1. Composition of different composted olive mill pomaces described in this chapter. OMP and OLM refer to olive mill pomace and olive leafy materials, respectively.

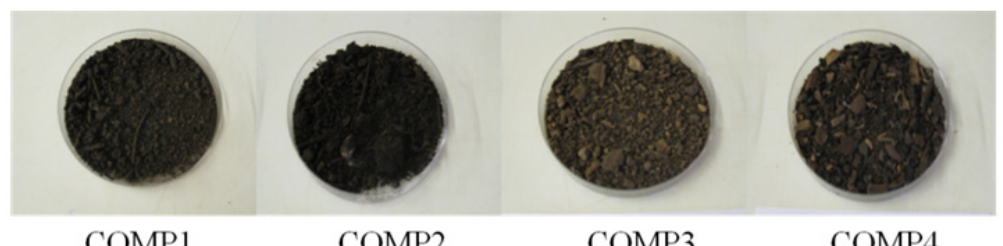
COMP1
COMP2
COMP3
COMP4

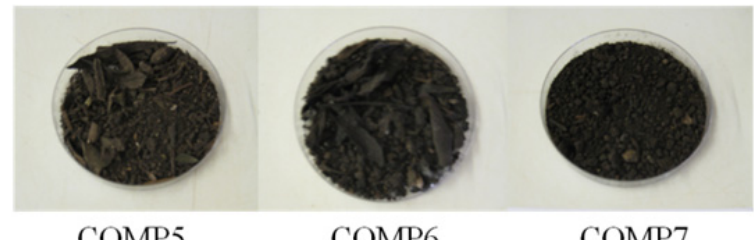

COMP5

COMP6

COMP7

Picture 1. Visual appearance of the composted olive mill pomace used in this study.

COMP $\mathrm{pH}$ ranged 7.45 to 8.34 and were adequate for most agricultural purposes. Those COMPs made of manure tended to have a higher $\mathrm{pH}$. Mean COMP $\mathrm{pH}$ was 8.03, a value 
similar to those reported by [20,23] for other experimentally-produced composts made of $\mathrm{OMP}$, and is within the $\mathrm{pH}$ range considered as optimal for the activity of microorganisms

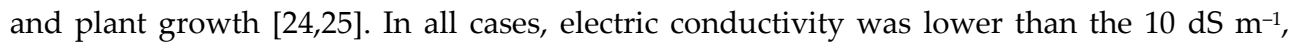
threshold established as indicator of possible phytotoxic/phyto-inhibitory effects on plants or in soil [26]. COMP has a high content of organic matter $(60.5 \%$, on average) and carbon (30.7\%, on average) (Table 2). These values are higher than those reported for cow, sheep and poultry manures and similar to those found for horse, pig and rabbit [27]. The highest values were found in those composts which included OLM and straw with little or no manure (COMP4 through to COMP7) and may be due to incomplete organic matter degradation of the larger particle sizes and the higher lignin content of OLM. A low organic matter degradation rate during composting has been reported [20], mainly because the high lignin content of the OMP and the high moisture of the initial mixture which limits sufficient aeration. For these COMPs, application to soil could be a good strategy to increase the organic matter content of soils of olive oil farms which in the Mediterranean basin are usually depleted in organic matter and are exposed to progressive degradation processes. Furthermore, the content of labile carbon in the COMPs are relatively low, indicating that respired carbon derived from compost after application to soil would be expected to be low. Therefore, COMP application to soil could increase $\mathrm{C}$ storage due to the high total carbon content and expected low rate of $\mathrm{C}$ mineralisation (see below).

Total nitrogen (TN) averaged 1.5\%, and was higher for those COMP which included relatively high amounts of manure during composting (Table 2). This values is within the range of that found for compost made from plant residues [28,29] and similar to that reported for compost produced experimentally with OMP plus rabbit or sheep manure, and rice straw or almond shells [22].

The C:N ratio ranged from 27.2 to 35.8 for COMP4, COMP5 and COMP6, which did not include, or contained only limited amounts of manure, while the ratio was much lower (at 10.5 - 18.7) for COMP1, COMP2, COMP3 and COMP7, which included sheep or poultry manures (Table 2).

The total $\mathrm{K}(\mathrm{TK})$ in the composts averaged $1.7 \%$ and was highest for COMP2, which included a high proportion of poultry manure and lowest for COMP4 and COMP5, both of which included straw (Table 2). These values were within the range of values reported by other authors [20,23] for experimentally-produced compost and also similar to those of OMP [13]. This indicates that $\mathrm{K}$ was not lost through leaching during the composting process. The total $\mathrm{P}$ of the composts averaged $0.41 \%$ and was highest for those amended with manure (COMP1, COMP2 and COMP3) and lowest for those which included only OLM or straw (Table 2). TP values were lower than those of municipal solid wastes and sewage sludge, although similar to other vegetable wastes and manures [30].

Those COMPs with a high percentage of manure had lower lignin contents, but lignin content tended to increase in those COMPs with a higher proportion of OLM and straw. Polyphenol contents of the COMPs were less than $2 \%$, even though OMP is usually characterized by high levels of polyphenols (Table 2). Polyphenols from olive oil mill waste 
water have been found to be toxic for some soil microorganisms [31], and this is one of the main reasons why direct application to soil cannot be recommended. The low polyphenol contents in the composts agree with values found by other researchers [32], who showed that the polyphenol content decreases during composting. In all cases, the polyphenol contents were lower than $4 \%$ : the limit which has been established where there is a shift between net $\mathrm{N}$ mineralization and immobilization during decomposition [33]. Those composts which are currently produced in Andalusia and which included manure showed typical lignin and polyphenol contents lower that $20 \%$ and $2 \%$, respectively and therefore are suitable as organic fertilisers. Lignin and polyphenol contents of residues have been shown to be robust indices for the prediction of $\mathrm{N}$ mineralisation from residue- $\mathrm{N}$ after incorporation in soil [34,35], with typical thresholds for immediate net $\mathrm{N}$ mineralisation being $<15 \%$ lignin and $<3-4 \%$ total extractable polyphenol contents [36-38].

COMPs phytotoxicities (Zuconni test) were typically higher than $50 \%$, except for COMP3 and COMP5, suggesting that a relatively high percentage of the currently produced COMPs are mature enough to be applied in the field.

\begin{tabular}{ccc}
\hline & $\begin{array}{c}\text { COMP commercially } \\
\text { produced } \\
\text { (min -mean- max) }\end{array}$ & Others authors $^{1}$ \\
\hline Organic matter $(\mathrm{LOI})\left(\mathrm{g} \mathrm{kg}^{-1}\right)$ & $272-605-879$ & $465-621$ \\
Total C $\left(\mathrm{g} \mathrm{kg}^{-1}\right)$ & $184-307-390$ & $301-491$ \\
Total N $\left(\mathrm{g} \mathrm{kg}^{-1}\right)$ & $10.7-15.0-20.0$ & $14.0-27.8$ \\
$\mathrm{C}: \mathrm{N}$ & $10.5-21.9-35.8$ & $14.0-22.7$ \\
Total P (\%) & $0.19-0.41-1.19$ & $0.5-1.5$ \\
Total $\mathrm{K}(\%)$ & $1.06-1.73-2.39$ & $20.6-39.5$ \\
Lignin $\left.(\mathrm{g} \mathrm{kg})^{-1}\right)$ & $76.0-218-313$ & $410-426$ \\
Polyphenols $(\%)$ & $0.94-1.33-2.1$ & - \\
Labile organic C $\left(\mathrm{g} \mathrm{kg}^{-1}\right)$ & $4.6-16.5-25.0$ & $7.3-10.2$ \\
\hline
\end{tabular}

Table 2. Main physico-chemical properties of seven commercially produced composted olive mill pomaces (Table 1) and results from bibliographic review of different authors for composted olive mill pomace. Values are mean of four replicates.

${ }^{1}$ Other authors $[19,20,21,22,23]$ for experimentally produced COMPs.

\subsection{Nutrient distribution in different particle size fractions of composted olive mill pomace}

The separation and application of different COMP particle sizes could provide for better optimization of COMP management, because a fairly clear relationship between particlesize distribution of an exogenous source of organic matter and the $\mathrm{C}$ and $\mathrm{N}$ dynamics in soils for sludge compost [39] (among others) has been demonstrated. Similarly, C mineralisation and turnover was seen to differ according to the particle-size fraction in a cattle slurry compost [40,41], also from a sludge-straw mixture [42] and in an aerobically digested sewage sludge composted along with screened green waste compost, stored yard 
trimmings and crushed wood pallets [39]. Moreover, the nitrogen availability in compost has also been shown to be related to particle size, increasing as particle size decreased in sludge compost [43]. Generally, N mineralisation is greater in the fine and water-soluble fractions than in coarser fractions, at least for manure and city refuse composts [44] and composted sewage sludge [39]. These results suggest that the size of fractions in compost contribute substantially to the total $\mathrm{C}$ and $\mathrm{N}$ dynamics of mineralisation after compost is incorporated into soil. This is of particular interest, because depending on the range in particle sizes, composts could therefore provide a means for storage of $\mathrm{C}$ in soil (i.e. from the larger sized compost fractions), or a source of available $\mathrm{N}$ (i.e. from the finer compost fractions). The diversity and variable amount of raw materials used to obtain COMP make the final products very heterogeneous and therefore, it is expected that the nutrients and the main physico-chemical properties also differ in the particle size fractions of COMP. However, no studies existed to corroborate this, therefore in a separate study we examined whether or not this expectation about COMP was correct.

To estimate the nutrient distribution in particle size fraction of COMP, seven commercially produced COMPs were studied (Table 1) by sieving successively through to obtain 3 different sized fractions: $<0.212,0.212-1.0$ and $1.0-60 \mathrm{~mm}$. About $52 \%$ of COMP particles were larger than $1 \mathrm{~mm}$ for those COMPs with a high content of manure, whereas, in contrast for COMPs without manure and with straw the consisted for $80 \%$ of these larger particle sizes. . The percentage of fine particles $(<0.212 \mathrm{~mm})$ doubled for COMPs with manure. These COMPs showed similar percentages of particle size fractions reported for duck manure [45], suggesting that during composting, manures generate a relatively high content of finer fractions. In general, the content of different compounds rich in organic $\mathrm{C}$, such as organic matter, total carbon and lignin increased with particle size, being significantly higher for fractions between 1 to $6 \mathrm{~mm}$. In sewage sludge compost made with screened refuse, yard trimmings and pallets [39], and for two types of dairy slurries others found [41], as in this study, an increase in the total $\mathrm{C}$ content with larger particles, although these differences were less distinct.

In contrast, nutrients contents including total $\mathrm{N}$, mineral $\mathrm{N}$, total $\mathrm{P}$ or total $\mathrm{K}$ were significantly higher in the fine fractions $(<0.212 \mathrm{~mm})$. More than $40 \%$ of the total $\mathrm{N}, \mathrm{P}$ and $\mathrm{K}$ found in the original COMPs were in the $<1 \mathrm{~mm}$ particle fractions in COMPs which included sheep or poultry manure during composting, whereas for COMP5, 6 and 7, the contribution of $<1 \mathrm{~mm}$ fractions was lower than $30 \%$. This finding agrees with those for manure and city refuse composts [44], animal slurry [41,45-47] and sludge compost [39], from workers who observed that most of the total $\mathrm{N}$ and various forms of $\mathrm{N}$ available in the short-term were mostly in the finer and water-soluble fractions.

As a result of lower $\mathrm{N}$, but higher $\mathrm{C}$, the $\mathrm{C}: \mathrm{N}$ ratio decreased as particle size increased (Figure 1). Similar relationships between $\mathrm{C}: \mathrm{N}$ ratio and particle size fractions were obtained for cattle slurry [46,47] and for sludge compost [39]. Typically, the C:N ratio for particles finer than $1 \mathrm{~mm}$ was lower than 18.2 in all COMPs, except those which included straw (COMP4 and COMP5), suggesting higher $\mathrm{N}$ availability of the organic $\mathrm{N}$ from these 
particles. During decomposition, manures with C:N ratios below 15 are likely to result in positive (net) $\mathrm{N}$ mineralisation after application to soil [48].

Overall, the germination index was higher than $80 \%$ in the $<1 \mathrm{~mm}$ fractions, whereas it was lower than $50 \%$ (e.g. with some degree of phytotoxicity) for fractions $1.0-6.0 \mathrm{~mm}$, although this was not true for COMPs made without manure (COMP5 and 6 mixtures) (Figure 1). Thus, the fractionation of the compost produced in olive mills containing $<1 \mathrm{~mm}$ phytotoxicity-free fractions is highly recommended for commercial purposes.

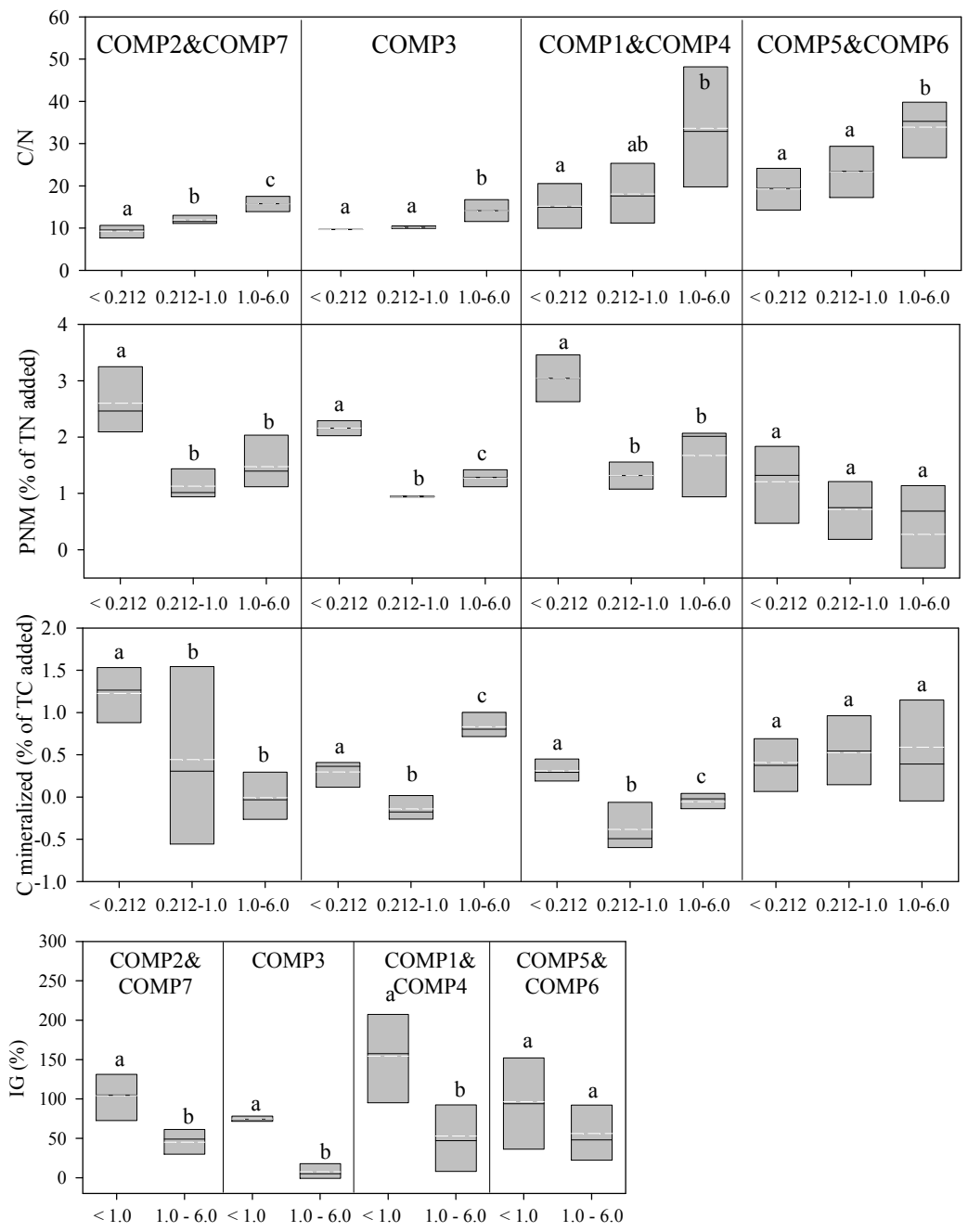

Figure 1. Box-plot of $\mathrm{C}: \mathrm{N}$, potential mineralisable $\mathrm{N}$ (PNM), mineralisable $\mathrm{C}$ and germination index of particle size fractions of combinations of COMPs according to the Principal Component Analysis. Different letters stand for significant differences $(\mathrm{P}<0.05)$ among particle size fractions. 
The main differences among seven COMP tested according their quality was shown in the Principal Component Analysis (Figure 2). First principal component (PC1), which was negatively correlated with COMP quality indicators (e.g. total and available nutrients, C:N ratio,...), categorized the COMPs according to the pool of nutrients and organic matter and $\mathrm{C}$, showing the high influence of raw materials in the quality of individual COMPs. Those COMPs made with poultry manure resulted in a high quality product, followed by COMPs made with sheep manure, whereas the quality of those COMPs made with a high proportion of OLM and straw but no manure was low. In addition, there was a trend for the quality to increase in relation to the content of finer fractions.

This highlighted the large influence of the raw materials in the final composition and quality of COMP product; a high proportion of manure increased the abundance of finer particles with high nutrients contents, whereas the addition of large amounts of OLM caused an increase in the content of larger particles with a high content of $\mathrm{C}$ compounds.

Overall, the separation and application of different COMP particle sizes could be useful for better optimization of COMP management, considering that the smallest particles $(<1 \mathrm{~mm})$ have a much higher germination index value, total $\mathrm{N}, \mathrm{P}$ and $\mathrm{K}$ and a higher potential to mineralise $\mathrm{N}$, providing a more homogeneous, high quality compost. On the other hand, larger particles $(>1 \mathrm{~mm}$ ) had higher contents of organic matter and $C$ and tended to have the lowest $C$ mineralisation and thus, on application to the soil in olive groves as a soil conditioner, could improve the structure and increase the organic matter of the poorer soils and increase the storage of soil organic $\mathrm{C}$.

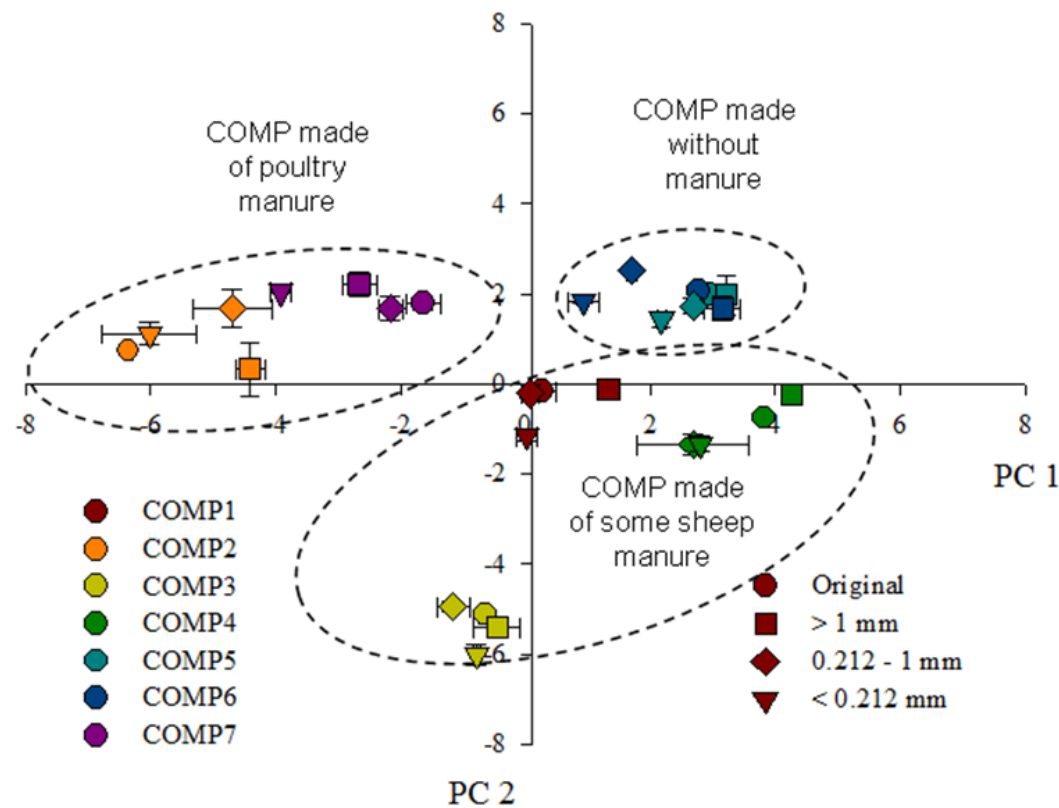

Figure 2. Scores of the whole and the particle size fractions of the COMPs in the space defined by PC1 and PC2. 


\section{Effects of composted olive mill pomace on nitrogen availability}

Although it is expected that the application of COMP-organic N would also supply some available $\mathrm{N}$ for the plant, there is little information on the decomposition rate of COMP and the impact this may have on the $\mathrm{N}$ available for the growth and productivity of olive trees.

Previous work [49] showed a relatively low net $\mathrm{N}$ mineralisation in soil after application of compost obtained from olive mill wastewater taken from an evaporative pond and other agricultural by-products, suggesting that during decomposition of composted OMP, N immobilization could take place.

More detailed knowledge of the main soil $\mathrm{N}$ transformations and dynamics, following COMP application to soil, could be the key to regulating soil fertility through an improved capability to predict crop available $\mathrm{N}$ and organic matter sequestration and losses.

\subsection{Nitrogen supply after the application of composted olive mill pomace}

Available nitrogen supply throughout net $\mathrm{N}$ mineralisation (NM) and nitrification was studied for commercially produced COMPs differing in the raw materials co-composted with OMP (Table 1) in an aerobic incubation experiment under controlled conditions over two years. The highest rates of NM for the control soil and COMP samples were found during the first week of incubation. This positive net $\mathrm{N}$ mineralisation was probably from the $\mathrm{N}$ and $\mathrm{C}$ contained in the labile components of the COMP, which can be used directly by microbes as an energy source. After the initial stage of mineral $\mathrm{N}$ release, net $\mathrm{N}$ immobilization during COMP decomposition was found. Probably because the microorganisms began to decomposed the more recalcitrant compounds (with a higher C:N ratio) and this placed a demand on available soil $\mathrm{N}$ resulting in net $\mathrm{N}$ immobilization, which can ultimately be re-mineralised over time. Similar rates of mineralisation were found with mature composted materials [50,51]. This result was unexpected since, according to the TN contents, C:N ratios and lignin contents of the different COMPs, net $\mathrm{N}$ mineralisation would be expected according to the view that the addition of organic matter generally causes $\mathrm{N}$ mineralisation [52-54]. Raw materials co-composted with OMP had effects on net $\mathrm{N}$ mineralization. During the first year of incubation, $\mathrm{N}$ immobilization was found in all COMPs, except for COMPs made chiefly from OMP and OLM. After two years, decomposition of COMP resulted in a positive net $\mathrm{N}$ mineralization (i.e. net mineral $\mathrm{N}$ supply) for all COMPs (Figure 3), with values as high as $95 \%$ of that added as COMP-N. These results demonstrate that the organic $\mathrm{N}$ contained in the COMPs is not readily available over short to medium timescales, and suggests that most of the organic $\mathrm{N}$ may be in relatively recalcitrant forms. Indeed, during the composting process, $\mathrm{N}$ is immobilised in condensed aromatic compounds which might contribute to the reduced availability of $\mathrm{N}$ [55]. Therefore, the application of COMP may result in short-term declines in N availability in agricultural soils: it is therefore recommended that during the first year, the application of COMP should be combined with some other N-rich source of fertilizer. On the other hand, autumn COMP application could be a useful approach to lowering soil inorganic $\mathrm{N}$ levels, thereby reducing potential $\mathrm{N}$ losses by leaching. 


\subsection{Application of composted olive mill pomace to soil reduce nitrogen losses by leaching}

Plant nitrogen use efficiency is usually lower than 50\%, though highly dependent on crop type and environmental conditions. There are different ways by which the $\mathrm{N}$ is lost and no longer available for crop uptake, such as denitrification, ammonia volatilization and leaching, which might also be associated with environmental problems. $\mathrm{N}$ leaching can contaminate groundwater or surface waters through runoff. Indeed, although $\mathrm{N}$ contamination of groundwater arises from several sources, such as industrial waste, municipal landfills, mining, or septic systems, agricultural practices remain a major source [56-58]. About $15-55 \%$ of $\mathrm{N}$ applied to crops can be lost by leaching every year $[59,60]$. This is particularly important in olive oil groves as many olive crops are on areas vulnerable to nitrate pollution.
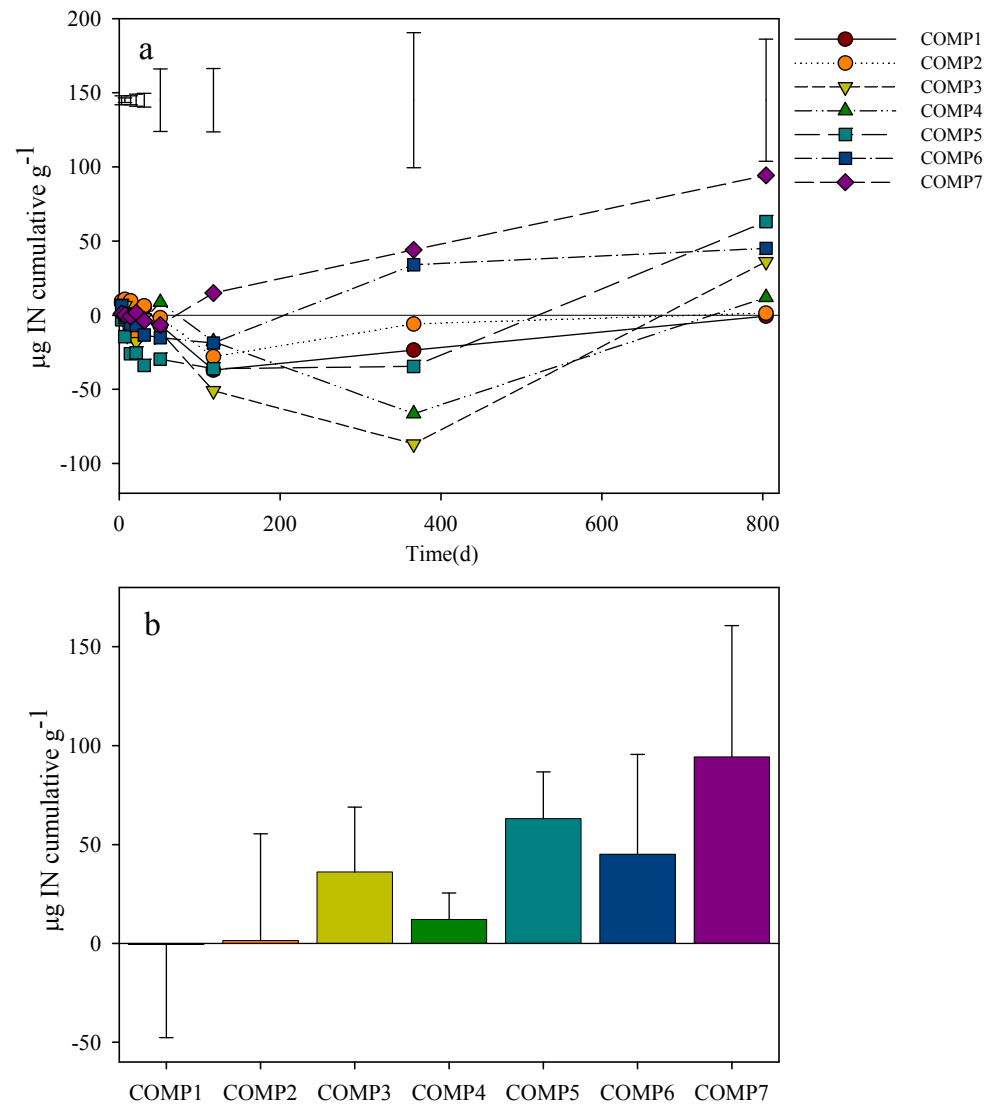

Figure 3. (a) Cumulative amounts of COMP-amended inorganic $N$ (IN) for each sampling period and (b) at the end of incubation ( $365 \mathrm{~d}$ ) for COMP amended soils. Bars for each sampling represent the mean of the standard deviations of the whole set of COMP-samples. 
Taking into account that $\mathrm{N}$ contained in COMP is not readily available in the short-term, $\mathrm{N}$ lost by leaching is expected to be low after application of COMP to soils. Indeed, short-term (51 days) leaching losses of $\mathrm{N}$ after application of COMP were similar or even lower (between -5 to $10 \%$ of the added $\mathrm{N}$ ) than the unamended control soils in an experiment carried out under laboratory conditions. These values were much lower than those found for commercial organic fertilizer (up to $30 \%$ of the added) and urea or sodium nitrate (up to $80 \%$ of the added) for the same amount of total $\mathrm{N}$ added (Figure 4 ).

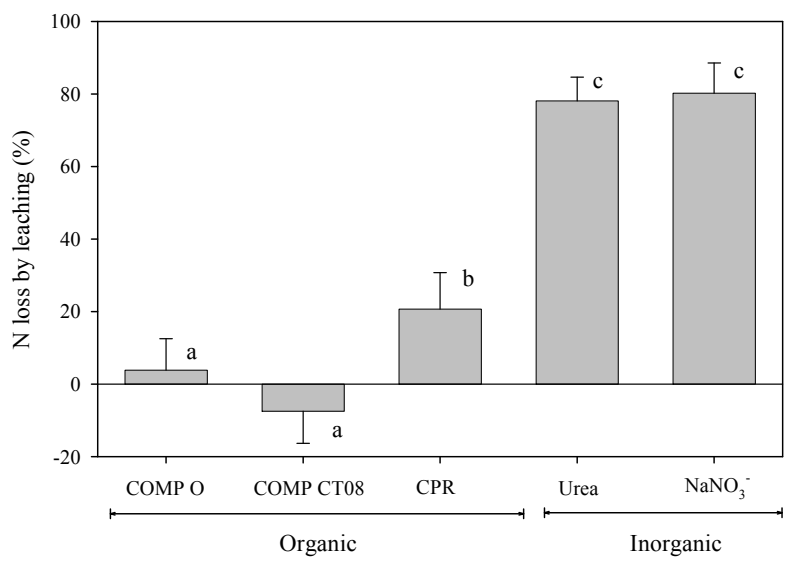

Figure 4. Percentage of $\mathrm{N}$ lost as nitrate by leaching of the total $\mathrm{N}$ added (equivalent to $100 \mu \mathrm{g} \mathrm{N} \mathrm{g}^{-1}$ ) after $51 \mathrm{~d}$ and three precipitation events (total precipitation equivalent to $801 \mathrm{~m}^{-2}$ ). Values are the mean of 4 replicates. Bar denotes standard deviation. Different letters denote significant differences between treatments $(\mathrm{P}<0.05)$.

Similar results were found in an experiment under outdoor conditions after one year. Nitrate leaching in soils amended with COMP was compared with soils amended with sheep manure (sheep M), commercial organic fertilizer (CPR), or inorganic fertiliser. Fertilisers were applied at two different rates (equivalent to 100 and $200 \mu \mathrm{g} \mathrm{N} \mathrm{g}^{-1}$ ) combined with two modes of application (on the soil surface or mixed with soil) and simulating autumn conditions. The lowest losses were for COMP amended soils (up to $7 \%$ of that applied) and the method of application had significant effects on mineral $\mathrm{N}$ leaching (Figure 5). In general, those soils which received COMP on the soil surface averaged negative mineral $\mathrm{N}$ losses (i.e. lower or similar losses to the control soil). $\mathrm{N}$ application rates had no effect on COMP IN leaching, regardless of the way the COMP was applied. Overall, inorganic $\mathrm{N}$ leaching for those treatments which received either Sheep M or CPR did not differ significantly, although leaching after surface application of CPR was higher than sheep M. Up to $37 \%$ of the fertiliser-derived $\mathrm{N}$ was leached for the 'double' surface application of CPR. No effects of rate or methods of application on IN leaching were found for CPR. However, for sheep M, leaching was higher at the double rate and lower for the 'surface', compared with the 'mixed in' application. The highest IN leaching reached $58 \%$ of the added $\mathrm{N}$ for inorganic fertiliser application (Figure 5). Results from the laboratory and outdoor experiment clearly showed 
the recalcitrant nature of the COMP-N (i.e. a high degree of $\mathrm{N}$ retention) despite the relatively low $\mathrm{C}: \mathrm{N}$ ratio, confirming previous results on $\mathrm{COMP}$-derived negative net $\mathrm{N}$ mineralisation and nitrification. Thus, application of COMP on olive oil farms distributed in the nitrate vulnerable areas might be a suitable strategy to diminish nitrate contaminated groundwater. This strategy agrees with [61] who reported that composted material can considerably lower the risk of groundwater contamination. Slow-release, controlled-release and stabilized fertilisers, such as composted OMP are recommended for several agro-environmental situations to improve nutrient use efficiency by reducing nutrient losses from the soil. Results from our studies clearly demonstrated the high efficiency of composted OMP to retain $\mathrm{N}$ and the beneficial reduction of nitrate leaching elicited by this compost.

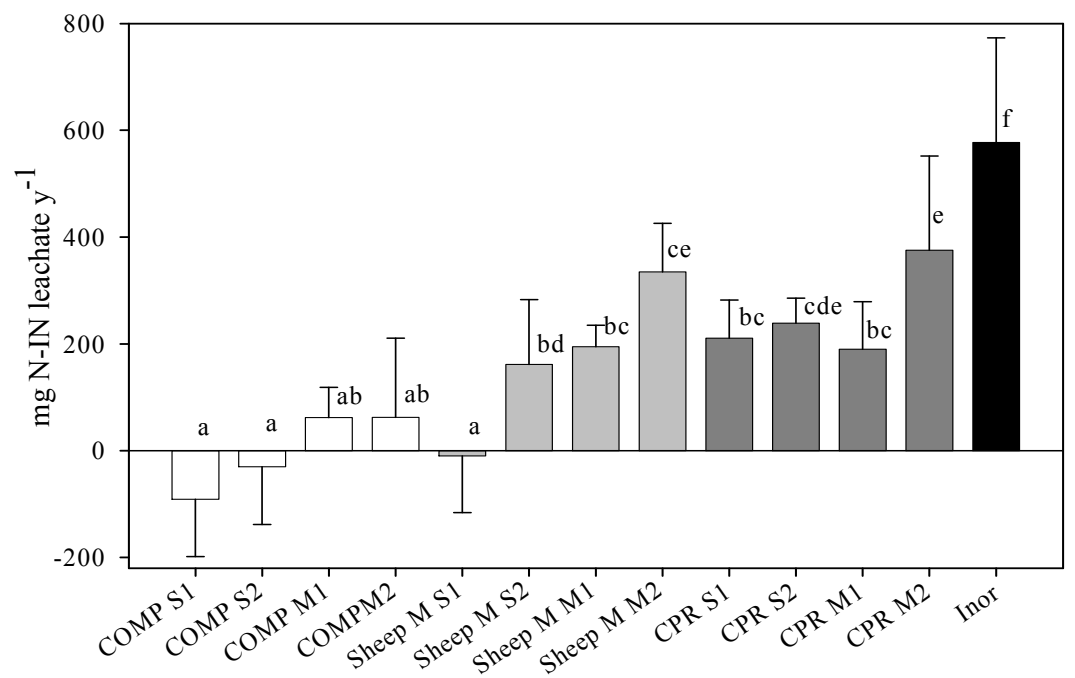

Figure 5. Cumulative fertiliser-derived mineral $\mathrm{N}$ (nitrate + ammonium) leaching after one year under natural rainfall and temperature in outdoor conditions for soils which received: i) composted olive mill pomace (COMP), ii) sheep manure (Sheep M), iii) commercial organic fertilisers (CPR), or iv) $\mathrm{NaNO}_{3}$ (Inor) at $1\left(250 \mu \mathrm{g} \mathrm{N} \mathrm{g}^{-1}\right)$ or $2\left(500 \mu \mathrm{g} \mathrm{N} \mathrm{g}^{-1}\right)$ doses. $\mathrm{M}$ and $\mathrm{S}$, stand for soil in which the fertilisers were mixed (M) with the soil or applied to the soil surface (S). Values are means of 4 replicates and bars denote standard deviations. Different letters denote significant differences $(P<0.05)$.

\section{3. $\mathrm{N}_{2} \mathrm{O}$ emission derived of application of composted olive mill pomace}

Agricultural soils are a significant source of atmospheric $\mathrm{N}_{2} \mathrm{O}$ which is of concern because of the role this gas has in global warming [62]. Emissions of $\mathrm{N}_{2} \mathrm{O}$ from soil have been shown to increase after the addition of plant residues [63] and organic fertilisers [64], the biochemical composition (or quality) being an important determinant of the magnitude of $\mathrm{N}_{2} \mathrm{O}$ emissions [65].

$\mathrm{N}_{2} \mathrm{O}$ emissions in soil amended with COMP $\left(100 \mu \mathrm{g} \mathrm{N} \mathrm{g}^{-1}\right)$ were determined under aerobic incubation over 51 days. Soil $\mathrm{N}_{2} \mathrm{O}-\mathrm{N}$ fluxes were constant and relatively low (2.71 ng $\mathrm{N}_{2} \mathrm{O}-\mathrm{N}$ $\left.\mathrm{g}^{-1} \mathrm{~d}^{-1}\right)$, and did not vary significantly between COMP-amended and the control soils, except 
for the COMP which was made with moderate levels of sheep manure (COMP1) (Figure 6). The cumulative $\mathrm{N}-\mathrm{N}_{2} \mathrm{O}$ emissions after 51 -days were only $0.23 \%$ of the added COMP-N. This result was not in agreement with the well documented increase in $\mathrm{N}_{2} \mathrm{O}$ emissions after plant residue addition to soils as reported in other studies [63,65]. The very low increase in $\mathrm{N}_{2} \mathrm{O}$ emissions after COMP application suggests that $\mathrm{N}$ losses via denitrification after the annual application of COMP to olive oil groves are expected to be very low, and thus application of COMP could provide organic $\mathrm{N}$ without increasing the emissions of $\mathrm{N}_{2} \mathrm{O}$
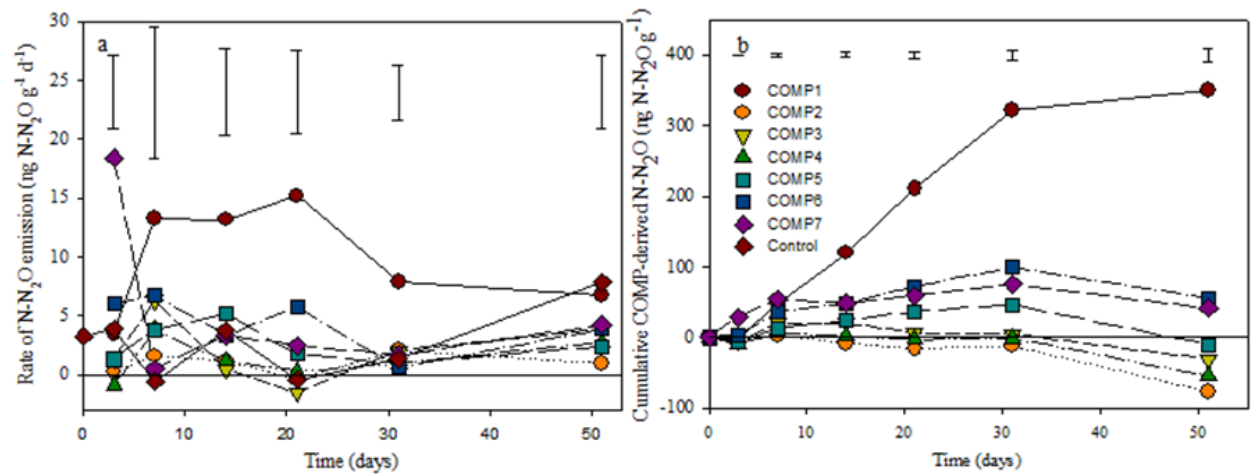

Figure 6. Time course of (a) N-N $2 \mathrm{O}$ emission rate and (b) cumulative $\mathrm{N}-\mathrm{N}_{2} \mathrm{O}$ emission in soil amended with COMP during 51 days of lab incubation under aerobic conditions. Bars denote the mean standard deviations for each treatment and sampling point.

\section{COMP-carbon mineralization}

As shown above, composted olive mill pomace (COMP) has a high content of total carbon, most of which of recalcitrant nature (e.g. expected low $\mathrm{C}$ decomposition) such as lignin or fibre. Therefore, COMP application in soil can be a good strategy to increase the organic matter content in soil, as well as the organic $\mathrm{C}$. This practice could reduce $\mathrm{CO}_{2}$ emission to the atmosphere increasing $\mathrm{C}$ storage in soil.

\subsection{Carbon mineralization}

Measurements of soil $\mathrm{CO}_{2}$ emissions can provide useful insights into soil $\mathrm{C}$ cycling, and provide a basis for evaluating soil $\mathrm{C}$ dynamics and potential $\mathrm{C}$ sequestration in different agricultural systems [66], particularly in intensive production systems affected by the different cropping practices and residue management [67]. Soil $\mathrm{C}$ can only be assimilated, and recycled through the microbial biomass, or respired [68]. Soil respiration and mineralisation are generally thought to be related to the composition of the microbial biomass, which in soils, tends to vary both across substrate qualities [69] and in time [70]. Low $\mathrm{C}$ mineralisation measured as $\mathrm{CO}_{2}-\mathrm{C}$ fluxes after mature COMP application have been shown [71]. However, the COMP used in this study was an experimentally produced COMP. The amount of COMP-C mineralized after 8 months of incubation after COMP 
application in eight soils differing in soil organic carbon (SOC) is shown in Figure 7. For all cases, the COMP-C mineralized (e.g. emitted as $\mathrm{C}-\mathrm{CO}_{2}$ ) was less than $10 \%$ of that added (4 g COMP-C $\mathrm{g}^{-1}$ ), and this was true, independently of soil texture or SOC contents. This result suggests that $\mathrm{C}$ compounds in COMP are complex and refractory, resulting in a high residence time in the soil. Moreover, the percentage of COMP-C mineralisation tended to be lower at higher rates of COMP application, which indicates a higher potential for COMP-C to accumulate in the soils at higher rates of application (Figure 8).

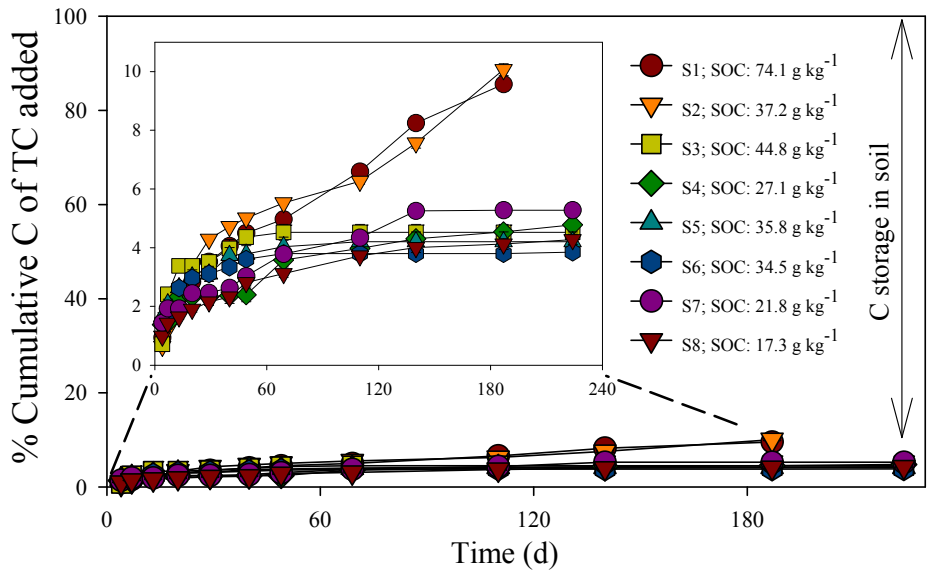

Figure 7. Percentage of $\mathrm{C}$ emitted as $\mathrm{CO}_{2}$ during $\mathrm{COMP}$ decomposition for eight types of soil after 240 days of incubation. Bars denote standards deviations.

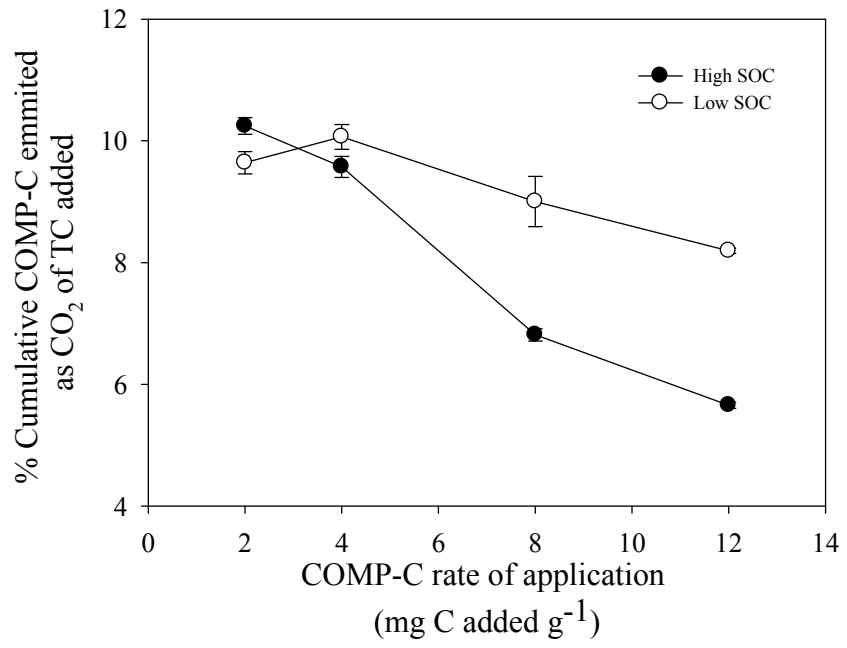

Figure 8. Effects of increasing the rate of COMP-C application to two soils differing in soil organic carbon (SOC) on cumulative COMP-C derived $\mathrm{C}-\mathrm{CO}_{2}$ emissions after 8 months of incubation. Bars denote standards deviations of three replicates. 


\section{Long-term effects of composted olive mill pomace application in olive groves}

The majority of the olive grove soils of Andalusia are characterised by low levels of organic matter, and are exposed to progressive degradation processes. Thus, organic matter application is required to compensate for organic carbon deficiency and to improve soil fertility. As a consequence, the use of a transformed agro-industrial waste for agricultural use, such as composted olive mill pomace, might represent a realistic solution to overcome both the soil degradation of olive oil groves and a sustainable disposal of OMP, thus increasing the sustainability of olive groves. Regional authorities, have recognised the potential use of COMP in agriculture, and have promoted composting which has resulted in an exponential increase in the production of COMP during the last 5 years, with a production of about 70000 tonnes in the 2009-2010 harvest campaign [18]. However, the long-term effects of annual application of COMP on the soil fertility of olive oil groves should be evaluated to promote more olive mill pomace composting.

Soil samples were taken from four olive oil farms; Olvera (O), Reja (R), Tobazo (T) and Andújar (A), which annually received applications of COMP during 3, 4, 9 and 16 years, respectively (COMP olive oil farms, hereafter). Soil samples were also taken from comparable olive oil farms located in the vicinity $(<20 \mathrm{~m})$ of each of the COMP farms that never received composted olive mill pomace (NCOMP, hereafter). These NCOMP farms have similar environmental conditions, topography and soil texture to the COMP farms. Soil samples were characterized for physico-chemical and biological variables to determine the fertility and functionality of soil after COMP application.

In general, soil $\mathrm{pH}$ in the 4, 9 and 16 years COMP sites was $0.31,0.23$ and 1.47 units lower than the comparable NCOMP olive farming, respectively, whereas no differences were achieved in the site after 3 years of COMP application. Moreover, the soil water holding capacity (WHC) was significantly higher in the COMP treated soils, with increases of $2-4 \%$ with respect to NCOMP soils. The higher (WHC) in the soils under COMP farming was expected (Table 3), due to the relatively higher levels of organic matter in these soils: the effect of organic matter on the increased potential for soils to retain water was described previously for 77 soil profiles [72]. Moreover, soil water aggregate stability was also significantly higher after COMP application for all treated soils: up to 1.5 - 2.5 times greater for COMP compared with NCOMP treated soils (Table 3). The higher soil aggregate stability in the COMP soils agrees with the findings of [73], who showed that the application OMP to soils increased this soil property from 64 to $73 \%$ after 5 years. The cation exchange capacity of soils treated with COMP was also significantly higher than in the relative NCOMP soils, independently of the site (e.g. number of years since COMP was first applied) (Table 3).

Overall, COMP application significantly increased both organic matter and carbon contents, compared with the NCOMP soil, except at the site that received COMP for only three years. The soil organic matter content in soils treated for 4, 9 and 16 years with COMP (i.e. R, T and A sites), was from 2.1 to 8.5 times greater than the respective NCOMP treated soil (Table 3). Our 
data confirmed previous results which indicated that soil organic matter increased after amendment with OMP during the first weeks after application [74] or after several years $[73,75]$. Our results also showed that organic carbon was higher in the COMP treatment compared with the NCOMP treatment. The increase in organic carbon after COMP application indicates that the decomposition rates of COMP-C were relatively low, and lower than the rates of annual COMP-C application. These recalcitrant compounds might contribute to the reduced rate of $\mathrm{C}$ decomposition. Soil organic carbon was higher in the soils treated with COMP, being up to eight times higher in soil where COMP was applied during the last 16 years in comparison with NCOMP farming. When extrapolating to a hectare scale, these results show that soil organic $C$ increased up to 30 tonnes per ha-1 $\mathrm{y}^{-1}$ in soil after COMP application. The low decomposition rate of COMP and high organic C content in COMPamended soil indicates that application of COMP in olive oil groves is an appropriate strategy to sequester organic carbon into the soil and should be evaluated further.

Overall, the total $\mathrm{N}$ content was higher in the COMP than in the NCOMP soils although this depended on the site. At $\mathrm{O}$ and $\mathrm{R}$ sites, which received three and four years of COMP application respectively, differences with the comparable NCOMP soils were not significant. However, total $\mathrm{N}$ was 1.3 and 14.8 times higher in soil with 9 and 16 years of COMP application (sites $\mathrm{T}$ and $\mathrm{A}$ ) than in the comparable NCOMP treated soils (Table 3). The higher TN in COMP soils was expected, since application of organic residues normally results in an increase in the soil content of $\mathrm{N}[49,73,76]$. They showed a significant increase in the TN after two to three years of application of OMP or COMP, indicating that COMP-N is very resistant to mineralisation, and therefore is retained in the soil.

Generally, soil labile phosphorus (P) in the amended COMP soils was higher than the unamended soil. In the $\mathrm{O}, \mathrm{R}$ and A sites, soil available $\mathrm{P}$ at the COMP soils was 13.9, 260.3 and $1607 \%$ higher than the NCOMP soil, whereas no significant difference was found at T site (Table 3). At all sites, soil exchangeable potassium was significantly higher in the COMP treated soils than in the unamended soils.

\begin{tabular}{|c|c|c|c|c|c|c|c|c|}
\hline Site & & WHC (\%) & SA (\%) & $\begin{array}{c}\text { CEC } \\
\left(\mathrm{meq}_{\left.100 \mathrm{~g}^{-1}\right)}\right.\end{array}$ & LOI (\%) & TC (\%) & $\mathrm{TN}(\%)$ & $\begin{array}{c}\text { Available P } \\
\left(\mu \mathrm{P} \mathrm{g} \mathrm{g}^{-1}\right)\end{array}$ \\
\hline \multirow[t]{2}{*}{$\mathrm{O}$} & COMP & $26.3 \pm 0.81^{\mathrm{a}}$ & $51.8 \pm 2.0^{\mathrm{a}}$ & $22.2 \pm 1.22^{\mathrm{a}}$ & 3.95 & 2.2 & $4^{a}$ & $10.6 \pm 0.04^{\underline{a}}$ \\
\hline & $\mathrm{NCO}$ & $22.3 \pm 0.3^{b}$ & $34.0 \pm 1.6^{b}$ & $20.8 \pm 0.21^{b}$ & 3.45 & & & $03^{\underline{a}}$ \\
\hline \multirow[t]{2}{*}{$\mathrm{R}$} & COMP & $21.8 \pm 1.3^{\mathrm{a}}$ & $57.9 \pm 1.8^{\mathrm{a}}$ & $25.3 \pm 3.83^{\underline{a}}$ & 8.34 & & & $30.3 \pm 0.03^{\underline{a}}$ \\
\hline & NCOMP & $20.5 \pm 1.7^{b}$ & $37.1 \pm 0.9^{b}$ & $18.6 \pm 0.27^{b}$ & 3.96 & 2.30 & $.02^{\mathrm{a}}$ & $11.5 \pm 0.02^{b}$ \\
\hline \multirow[t]{2}{*}{$\mathrm{T}$} & COMP & $23.6 \pm 0.5^{a}$ & $56.7 \pm 0.2^{\mathrm{a}}$ & $21.1 \pm 3.46^{\mathrm{a}}$ & & & & $6.9 \pm 0.01^{\mathrm{a}}$ \\
\hline & NCOMP & $20.5 \pm 0.8^{b}$ & $22.6 \pm 0.6^{b}$ & $15.4 \pm 2.06^{b}$ & $2.39 \pm 0$ & 1.39 & $.02^{b}$ & $7.6 \pm 0.02^{\mathrm{a}}$ \\
\hline \multirow[t]{2}{*}{ A } & COMP & $30.2 \pm 0.5^{\mathrm{a}}$ & $23.9 \pm 1.0^{\mathrm{a}}$ & $23.3 \pm 6.9^{\mathrm{a}}$ & $16.1 \pm 3.49^{a}$ & 8.49 & $0.74 \pm 0.33^{a}$ & $57.4 \pm 0.33^{\mathrm{a}}$ \\
\hline & NCOMP & $28.7 \pm 1.3^{a}$ & $23.7 \pm 1.5^{\mathrm{a}}$ & $10.6 \pm 1.2^{b}$ & $1.88 \pm 0.41^{\mathrm{b}}$ & $1.09 \pm 0.21^{b}$ & $0.05 \pm 0.02^{b}$ & $3.57 \pm 0.02^{b}$ \\
\hline
\end{tabular}

Table 3. Water holding capacity (WHC), soil stables aggregates (SA), cation exchangeable capacity (CEC), organic matter (LOI), total C (TC), total $\mathrm{N}(\mathrm{TN})$ and available $\mathrm{P}$ of olive oil farming which received (COMP) or not (NCOMP) composted olive mill pomace at Olvera (O), Reja (R), Tobazo (T) and Andújar (A). Data are the mean of five replicates \pm standard deviation. Different superscript letters for each site denote significant differences between COMP and NCOMP farming (one way ANOVA; $\mathrm{P}<$ 0.05). 

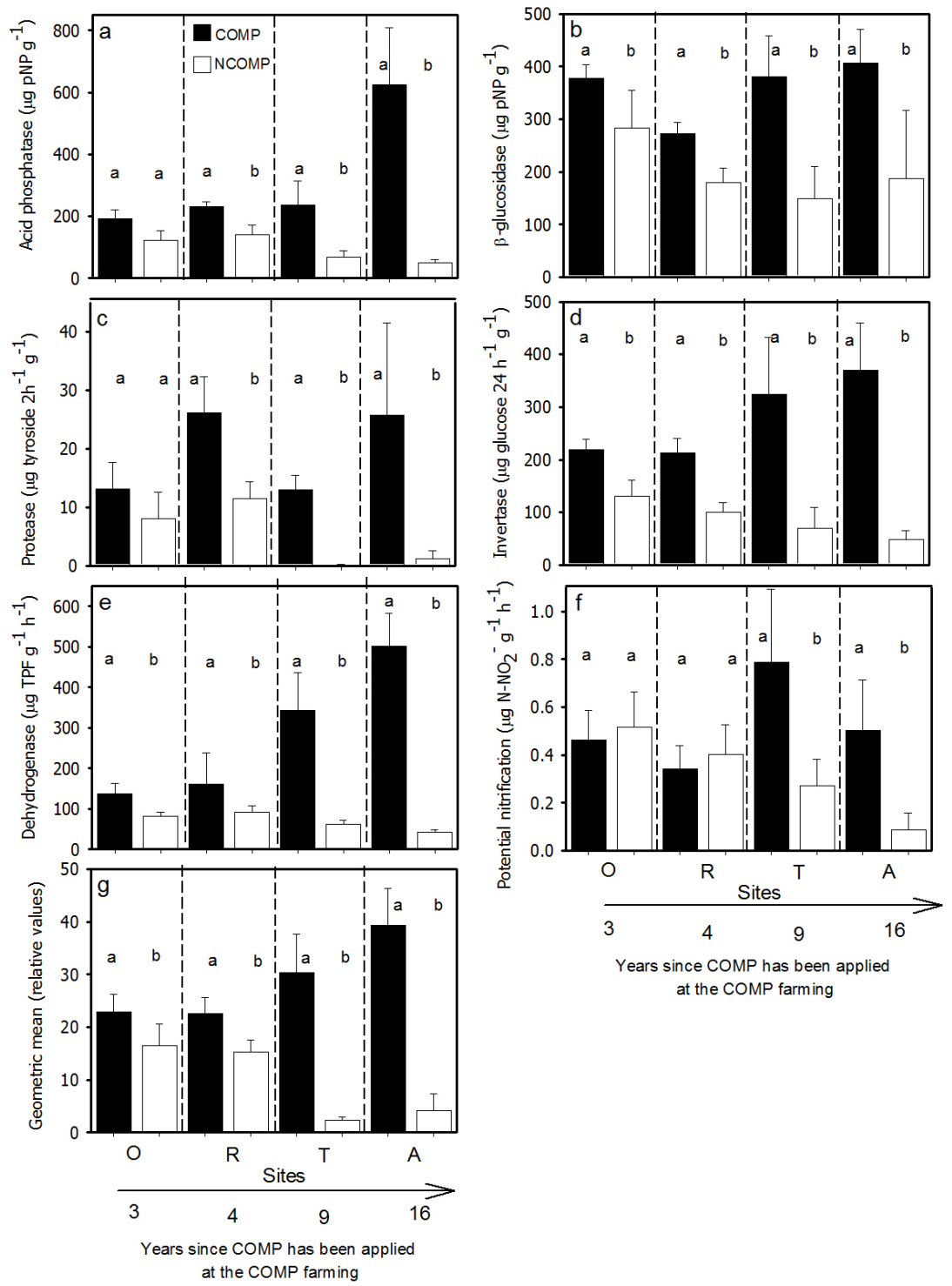

Figure 9. Soil acid phosphatase (a), $\beta$-glucosidase (b), protease (c), invertase (d), and dehydrogenase (e) activities, potential nitrification rate (f) and geometric mean of the assayed soil enzyme in olive oil farms which received (black) or not (white) COMP at Olvera (O), Reja (R), Tobazo (T) and Andújar (A). The number of years since composted olive mill pomace has been applied to COMP farming is also indicated. Different subscript letters stand for significant differences $(\mathrm{P}<0.05)$ between COMP and NCOMP farming of each site.

Soil enzyme activities related to carbon, nitrogen and phosphorus cycling have been proposed as a tool to assess soil quality/health and functioning [77]. Enzymes activities 
related to the $\mathrm{C}, \mathrm{N}$ and $\mathrm{P}$ cycles were all significantly higher in soils amended with COMP than in NCOMP soils (Figure 9). Others authors [78,79] have found similar results after application of manures of different origin.

When pooling all the analysed variables in a Principal Component Analysis it was found that the first principal component (PC1) was negatively correlated with soil organic matter, total $\mathrm{N}$, available $\mathrm{P}$, soil aggregate stability and soil enzyme activities and therefore, PC1 is strongly related to soil functioning. PC2, on the other hand, was positively correlated with clay content, WHC and cation exchange capacity. COMP-treated soils shifted upwards (higher WHC and CEC) and towards the left (higher soil functioning) with respect to their NCOMP soils in the PC1-PC2 space (Figure 10). Therefore PCA, which included all the analysed variables, clearly separated paired plots according to the COMP application, supporting the hypothesis that COMP application improves overall soil functioning.

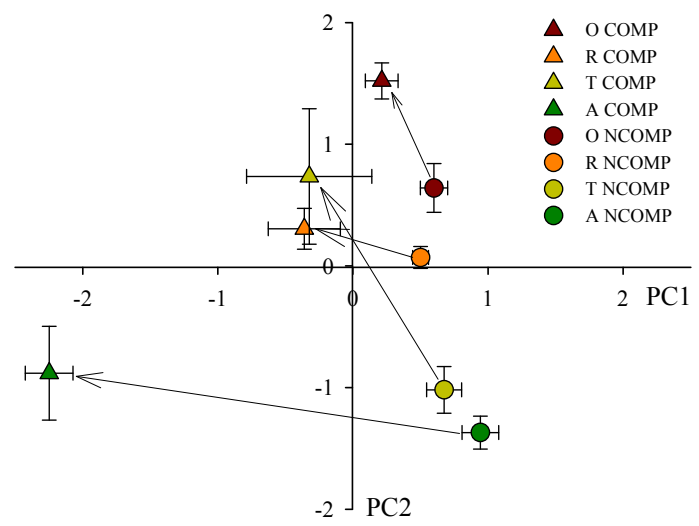

Figure 10. Ordination of the COMP and NCOMP farms at Olvera $(\mathrm{O})$, Reja (R), Tobazo (T) and Andújar (A) in the space defined by the PC1 and PC2 axis resulting from the PCA analysis carried out with physico-chemical and biochemical soil properties. Coordinates are the means of $t$ five replicates and bars represent the standard deviations of the mean. Arrows illustrate the differences in the position of the COMP and NCOMP farming at each site.

Finally, the vectorial distance between comparable COMP and NCOMP farms (e.g. differences in soil functioning) tended to increase with the period of COMP application, suggesting that there is potential for further increases in soil fertility and functioning after long-term application of COMP.

\section{Ecological services associated with the use of composted olive mill pomace as organic fertiliser}

There is a global trend towards developing agricultural production systems which are sustainable. This involves the more efficient utilisation of inputs and the reduction of waste products. Ideally, organic by-products should be transformed into useful products by 
processes such as nutrient recycling, replenishment of soil organic matter or generation of energy. In this context, the cost of waste disposal would be avoided and environmental pollution reduced. This fact has led y to a widespread increase in the value of by-products of the agricultural industry. This is also now the case for OMP.

Recycling of OMP through composting (relatively easy-to-use and low costing methodology) could be a sound strategy to provide some ecological services to olive oil groves (Figure 11). Firstly, composting OMP reduces most of the potential environmental pollution problems linked with the disposal of approximately 4 million of tonnes of OMP produced in Andalusia over a relatively short-time span (3 months). On the other hand, most of the nutrients (especially nitrogen, phosphorus and potassium) harvested with the yield, are contained in the OMP, and therefore after composting and application to olive oil groves helps to recycle these nutrients, reducing the need for chemical fertilisers. Our estimates show that between one to two-thirds of the Andalusian olive oil groves could be fertilised annually with the OMP produced in Andalusia after composting, with a subsequent reduction of about 25 $60 \%$ in chemical fertilisers. In addition, the main beneficiary of the economic and environmental profits of composting OMP and application to olive oil groves is the farmer.

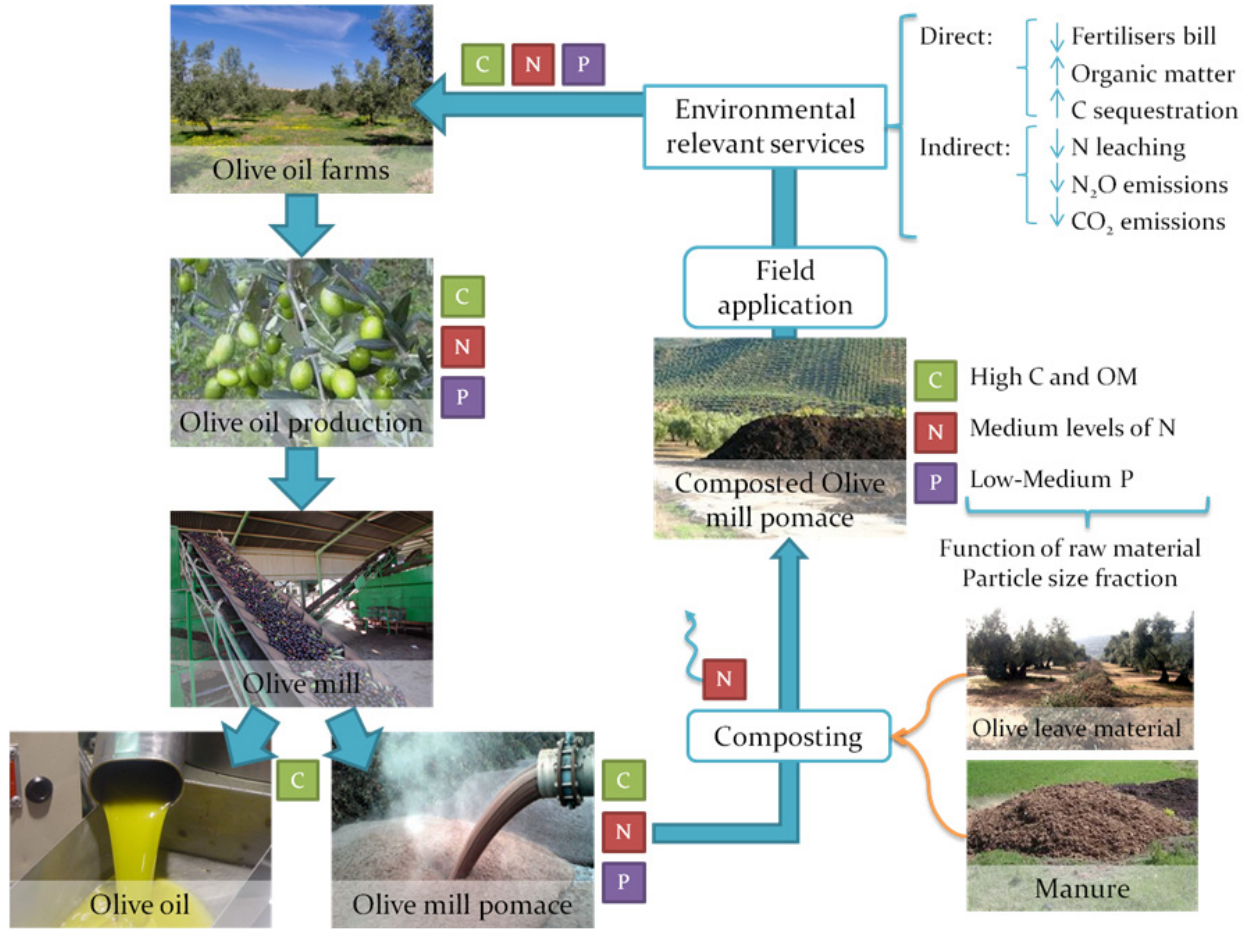

Figure 11. Fate of $\mathrm{C}, \mathrm{N}$ and $\mathrm{P}$ of the fruit harvested in the olive oil farming when olive mill pomace (main by-product of the olive oil mill industry) is composted and applied to the olive oil groves. Some of the environmental services linked to the recycling of olive mill pomace throughout composting, are also indicated. 
Some of the environmental services restored after application of COMP and shown in this chapter include: i) Increased soil organic matter and carbon. Indeed our data showed that both increased significantly after regular applications of COMP and there was a trend for increased differences in SOM and SOC between soils amended or unamended with COMP according to the number of years when COMP was applied. Other variables related directly or indirectly with the increase in SOM include i) an increase in soil microbial activity related to nutrient recycling (e.g. soil enzyme activities), cation exchange capacity, soil aggregate stability and available $\mathrm{P}$ and $\mathrm{K}$, ii) increase in soil carbon sequestration. COMP-C derived mineralization is rather low ( $<10 \%$ over one year at optimal conditions) and thus, regular applications of COMP could contribute to soil $\mathrm{C}$ sequestration and help alleviate the soil C$\mathrm{CO}_{2}$ emissions linked to olive oil cultivation, iii) reduction of the potential nitrate leaching and $\mathrm{N}_{2} \mathrm{O}$ emissions. Our data on seven currently produced COMPs have demonstrated that during decomposition of $\mathrm{OMP}$, soil mineral $\mathrm{N}$ is retained (i.e. net $\mathrm{N}$ immobilization) reducing not only nitrate leaching, but also $\mathrm{N}_{2} \mathrm{O}$ emissions.

\section{Conclusions}

The recycling of nutrient and organic matter of the olive mill pomace after its composting and application to the soil of olive oil farming is a worthwhile strategy to avoid the potential environmental harm of olive mill waste disposal and could lead to increased soil fertility and functionality. The characteristics of the COMP currently produced are adequate for agricultural purposes (high organic matter and carbon, high level of potassium and from low to medium levels of $\mathrm{N}$ and $\mathrm{P}$, and lack of phytotoxicity) and the quality was highly dependent on the proportion of manure co-composted with olive mill pomace. COMP-N is well humified and during decomposition soil mineral $\mathrm{N}$ can be immobilised depending on the proportion of raw materials co-composted, and therefore it is recommended to combine $\mathrm{N}$ rich fertiliser with COMP during the first years of COMP application. COMP-nitrate leaching (at a temporal scale of months to a year) and nitrous oxide emissions were negligible after COMP application to soils. COMP-C mineralization was very low $(<10 \%$ of that added after one year) and, therefore, COMP application to soils could enhance $\mathrm{C}$ sequestration in olive oil farming. Soil fertility and functioning was improved after three years of regular applications of COMP to soils of olive oil groves a there was a clear trend for a further increase over longer periods of application.

Overall, composted olive mill pomace is a worthwhile strategy to reduce the environmental problems associated with the disposal of OLM, and increases the sustainability and ecological services of olive oil cultivation.

\section{Author details}

Beatriz Gómez-Muñoz

Corresponding Author

Ecology Section, University of Jaén, Campus Las Lagunillas s/n, Jaén, Spain 
David J. Hatch

Sustainable Soils and Grassland Systems Department, Rothamsted Research, North Wyke,

Okehampton, Devon, UK

Roland Bol

Institute of Bio-and Geosciences, Agrosphere (IBG-3), Forschungszentrum Jülich GmbH, Jülich, Germany

Roberto García-Ruiz

Ecology Section, University of Jaén, Campus Las Lagunillas s/n, Jaén, Spain

\section{Acknowledgement}

This research was carried out in the framework of the "Olive grove project" of the General Secretary for Rural Development and organic production of the Junta de Andalucía, and with the economic help of the Minister of Science and Technology of Spain throughout the project referenced CGL200908303. We would like to thanks to Jose María Álvarez and the various olive oil farmers and olive oil mills from which soil and composted olive mill pomace samples were taken.

\section{References}

[1] Beaufoy G, Pienkowski M (2000) The environmental impact of olive oil production in the European Union: practical options for improving the environmental impact. European Forum on Nature Conservation and Pastoralism. European Commission, Brussels.

[2] Dios-Palomares R, Haros-Giménez D, Montes-Tubio F (2005) Estudio estructural del sector oleícola de Andalucía. Nivel de calidad y respecto medioambiental de las industrias almazaras. Comunicaciones EXPOLIVA.

[3] Moraetis D, Stamati FE, Nikolaidis NP, Kalogerakis N (2011) Olive mill wastewater irrigation of maize: impacts on soil and groundwater. Agr. Water Manage. 98: 11251132.

[4] Cabrera F, López R, Martinez-Bordiú A, Dupuy de Lome E, Murillo JM (1996) Land treatment of olive oil mill wastewater. Int. Biodeter. Biodegr. 38: 215-225.

[5] Kavvadias V, Doula MK, Komnitsas K, Liakopoulou N (2010) Disposal of olive oil mill wastes in evaporation ponds: effects on soil properties. J. Hazard. Mater. 182: 144-155.

[6] López-Piñeiro A, Cabrera D, Albarrán Á, Peña D (2011) Influence of two-phase olive mill waste application to soil on terbuthylazine behaviour and persistence under controlled and field conditions. J. Soil Sediment. 11: 771-782.

[7] Paredes MJ, Moreno E, Ramos-Cormenzana A, Martinez J (1987) Characterization of soil after pollution with waste waters from olive oil extraction plants. Chemosphere. 16: 1557-1564.

[8] Pérez J, de la Rubia T, Moreno J, Martinez J (1992) Phenolic content and antibacterial activity of olive mill wastewater. Environ. Toxicol. Chem. 11: 489-495. 
[9] Linares A, Caba JM, Ligero F, De la Rubia T, Martínez J (2003) Detoxification of semisolid olive-mill wastes and pine-chip mixtures using Phanerochaete flavido-alba. Chemosphere. 51: 887-891.

[10] Sierra J, Marti E, Garau MA, Cruanas R (2007) Effects of agronomic use of olive oil mill wastewater - field experiment. Sci. Total Environ. 378: 90-94.

[11] Piotrowska A, Rao MA, Scotti R, Gianfreda L (2011) Changes in soil chemical and biochemical properties following amendment with crude and dephenolized olive mill waste water (OMW). Geoderma. 161: 8-17.

[12] Paredes C, Cegarra J, Roig A, Sánchez-Monedero MA, Bernal MP (1999) Characterization of olive mill wastewater (alpechin) and its sludge for agriculture purposes. Bioresource Technol. 67: 111-115.

[13] Alburquerque JA, Gonzálvez J, García D, Cegarra J (2004) Agrochemical characterisation of "alperujo", a solid by-product of the two-phase centrifugation method for olive oil extraction. Bioresource Technol. 91: 195-200.

[14] Roig A, Cayuela ML, Sánchez-Monedero MA (2006) An overview on olive mill wastes and their valorisation methods. Waste Manage. 26: 960-969.

[15] Cayuela ML, Millner P, Slovin J, Roig (2007) Duckweed (Lemna gibba) growth inhibition bioassay for evaluating the toxicity of olive mill wastes before and during composting. Chemosphere. 68: 1985-1991.

[16] Madejón E, Galli E, Tomati U (1998) Composting of wastes produced by low water consuming olive mill technology. Agrochimica. 42: 135-146.

[17] Cegarra J, Amor JB, Gonzálvez J, Bernal MP, Roig A (2000) Characteristics of a new solid olive-mill-by-product ("alperujo") and its suitability for composting. In: Warman, P.R, Taylor, B.R. (Eds.), Proceedings of the International Composting Symposium ICS_99, 1. CBA Press Inc, pp. 124-140.

[18] Álvarez de la Puente JM, Jáuregui J, García-Ruiz R (2010) Composting olive mill pomace: The Andalusian experience. Biocycle. 31-32.

[19] García-Gómez A, Roig A, Bernal MP (2003) Composting of the solid fraction of olive mill wastewater with olive leaves: organic matter degradation and biological activity. Bioresource Technol. 86: 59-64.

[20] Alburquerque JA, Gonzálvez J, García D, Cegarra J (2006) Measuring detoxification and maturity in compost made from "alperujo", the solid by-product of extracting olive oil by the two-phase centrifugation system. Chemosphere. 64: 470-477.

[21] Canet R, Pomares F, Cabot B, Chaves C, Ferrer E, Ribó M, Albiach MR (2008) Composting olive mill pomace and other residues from rural southeastern Spain. Waste Manage. 28(12): 2585-2592.

[22] Alburquerque JA, Gonzálvez J, García D, Cegarra J (2007) Effects of a compost made from the solid by-product ("alperujo") of the two-phase centrifugation system for live oil extraction and cotton gin waste on growth and nutrient content of ryegrass (Lolium perenne L.). Bioresource Technol. 98: 940-945.

[23] Hachicha S, Sellami F, Medhioub K, Hachicha R, Ammar E (2008) Quality assessment of composts prepared with olive mill wastewater and agricultural wastes. Waste Manage. 28(12): 2593-603. 
[24] Mustin M (1987) Le Compost: Gestion de la Matie `re Organique. Dubusc, F. (Ed.), Paris, pp. 117-263.

[25] Das KC (2007) Co-composting of alkaline tissue digester effluent with yard trimmings. Waste Manage. 28: 1785-1790.

[26] Iannotti DA, Grebus ME, Toth BL, Madden LV, Hoitik HAJ (1994) Oxygen respirometric method to assess stability and maturity of composted municipal solid waste. J. Environ. Qual. 23: 1177-1183.

[27] Moral R, Moreno-Caselles J, Pérez-Murcia MD, Pérez-Espinosa A, Rufete B, Paredes C (2005) Characterisation of the organic matter pool in manures. Bioresource Technol. 96(2): 153-158.

[28] Sánchez-Monedero MA, Roig A, Paredes C, Bernal MP (2001) Nitrogen transformation during organic waste composting by the Rutgers system and its effects on $\mathrm{pH}, \mathrm{EC}$ and maturity of the composting mixtures. Bioresource Technol. 78: 301-308.

[29] Goyal S, Dhull SK, Kapoor KK (2005) Chemical and biological changes during composting of different organic wastes and assessment of compost maturity. Bioresource Technol. 96(14): 1584-1591.

[30] Pascual JA, Ayuso M, García C, Hernández T (1997) Characterization of urban wastes according to fertility and phytotoxicity parameters. Waste Manage. Res. 15: 103-112.

[31] Capasso R, Evidente AA, Schivo L, Orru, G, Marcialis, M.A, Cristinzio, G, 1995. Antibacterial polyphenols from olive oil mill waste waters. J. Appl. Bacteriol. 79: 393398.

[32] Ait Baddi G, Alburquerque JA, Gonzalvez J, Cegarra J, Hafidi M (2004) Chemical and spectroscopic analyses of organic matter transformations during composting of olive mill wastes. Int. Biodeter. Biodegr. 54(1): 39-44.

[33] Palm CA, Gachengo CN, Delve RJ, Cadisch G, Giller KE (2001) Organic inputs for soil fertility management in tropical agro ecosystems: application of an organic resource database. Agr. Ecosyst. Environ. 83: 27-42.

[34] Fox RH, Myers RJK, Vallis I (1990) The nitrogen mineralization rate of legume residues in soil as influenced by their polyphenol, lignin and nitrogen contents. Plant Soil. 129: 251-259.

[35] Palm CA, Sánchez PA (1991) Nitrogen release from the leaves of some tropical legumes as affected by their lignin and polyphenolic contents. Soil Biol. Biochem. 23: 83-88.

[36] Melillo JM, Aber JD, Muratore JF (1982) Nitrogen and lignin control of hardwood leaf litter decomposition dynamics. Ecology, 63: 621-626.

[37] Constantinides M, Fownes JH (1994) Nitrogen mineralization from leaves and litter of tropical plants - relationship to nitrogen, lignin and soluble polyphenol concentrations. Soil Biol. Biochem. 26: 49-55.

[38] Palm CA, Rowland AP (1997) A minimum data set for characterization of plant quality for decomposition. In: G. Cadisch and K.E. Giller, Editors, Driven by Nature: Plant Litter Quality and Decomposition, CAB International, Wallingford. 379-392.

[39] Doublet J, Francou C, Pétraud JP, Dignac MF, Poitrenaud M, Houot S (2010) Distribution of $\mathrm{C}$ and $\mathrm{N}$ mineralization of a sludge compost within particle-size fractions. Bioresource Technol. 101(4): 1254-1262. 
[40] Grilo J, Bol R, Dixon L, Chadwick D, Fangueiro D (2011) Long term release of carbon from grassland soil amended with different slurry particle size fractions: a laboratory incubation study. Rapid Commun. Mass Sp. 25: 1514-1520.

[41] Fangueiro D, Chadwick D, Dixon L, Bol R (2007) Quantification of priming and $\mathrm{CO}_{2}$ respiration sources following the application of different slurry particle size fractions to a grassland soil. Soil Biol. Biochem. 39: 2608-2620.

[42] Robin P, Ablain F, Yulipriyanto H, Pourcher AM, Morvan T, Cluzeau D, Morand P (2008) Evolution of non-dissolved particulate organic matter during composting of sludge with straw. Bioresource Technol. 99: 7636-7643.

[43] Tester CF, Sikora LJ, Taylor JM, Parr JF (1979) Decomposition of sewage sludge compost in soil: III. Carbon, nitrogen, and phosphorus transformations in different sized fractions, J. Environ. Qual. 8: 79-82.

[44] Aoyama M (1985) Properties of fine and water-soluble fractions of several composts. Micromorphology, elemental composition and nitrogen mineralization of fractions. Soil Sci. Plant Nutr. 31: 189-198.

[45] Fangueiro D, Gusmão M, Grilo J, Porfírio G, Vasconcelos E, Cabral F (2010) Proportion, composition and potential $\mathrm{N}$ mineralisation of particle size fractions obtained by mechanical separation of animal slurry. Biosyst. Eng. 106: 333-337.

[46] Fangueiro D, Bol R, Chadwick D (2008a) Assessment of the potential N mineralization of six particle size fractions of two different cattle slurries. J. Plant Nutr. Soil Sc. 171: 313-315.

[47] Fangueiro D, Pereira J, Chadwick D, Coutinho J, Moreira N, Trindade H (2008b) Laboratory assessment of the effect of cattle slurry pre-treatment on organic $\mathrm{N}$ degradation after soil application and $\mathrm{N}_{2} \mathrm{O}$ and $\mathrm{N}_{2}$ emissions. Nutr. Cycl. Agroecosys. 80: 107-120.

[48] Beauchamp EG, Paul JW (1989) A simple model to predict manure N availability to crops in the field. In: J.A. Hansen and K. Henriksen, Editors, Nitrogen in Organic Wastes Applied to Soils, Academic Press, London.

[49] Cabrera F, Martín-Olmedo P, López R, Murillo JA (2005) Nitrogen mineralization in soils amended with composted olive mill sludge. Nutr. Cycl. Agroecosys. 71: 249-258.

[50] Parker CF, Sommer LE (1983) Mineralization of nitrogen in sewage sludges. J. Environ. Qual. 12: 150-156.

[51] Hérbert M, Karam A, Parent LE (1991) Mineralization of nitrogen and carbon in soils amended with composted manure. Biology, Agriculture and Horticulture, 7: 349-361.

[52] Chae YM, Tabatabai MA (1986) Mineralization in an aridisol mixed with various organic materials. J. Environ. Qual. 15: 193-198.

[53] Bernal MP, Kirchmann H (1992) Carbon and nitrogen mineralization and ammonia volatilization: from fresh, aerobically and anaerobically treated pig manure during incubation with soil. Biol. Fert. Soils, 13: 135-140.

[54] Hadas A, Portnoy R (1994) Nitrogen and carbon mineralization rates of composted manures incubated in soil. J. Environ. Qual. 23: 1184-1189. 
[55] Senesi N, Plaza C, Brunetti G, Polo A (2007) A comparative survey of recent results on humic-like fractions in organic amendments and effects on native soil humic substances. Soil Biol. Biochem. 39: 1244-1252.

[56] Ferguson RB, Shapiro CA, Hergert GW, Kranz WL, Klocke NL, Krull DH (1991) Nitrogen and irrigation management practices to minimize nitrate leaching from irrigated corn. J. Prod. Agric. 4: 186-192.

[57] Hallberg GR (1985) Agricultural chemicals and groundwater quality in Iowa: Status Report, Cooperative Extension Service, CE-2158q, Iowa State Univ, Ames, IA, p. 11.

[58] Stanley EH, Short RA, Harrison JW, Hall R, Wiedenfeld RC (1990) Variation in a nutrient limitation of lotic and lentic algal communities in a Texas (USA) river. Hydrobiologia. 206: 61-71.

[59] Hallberg GR (1989) Nitrate in ground water in the United States. In R.F. Follett (ed.) Nitrogen management and ground water protection. Elsevier, New York, p. 35-74.

[60] Yadav SN (1997) Formulation and estimation of nitrate-nitrogen leaching from corn cultivation. J. Environ. Qual. 26: 808-814.

[61] Insam H, Merschak P (1997) Nitrogen leaching from forest soil cores after amending organic recycling products and fertilizers. Waste Management Research, 15: 277-292.

[62] IPCC (2007) Changes in Atmospheric Constituents and in Radiative Forcing, Cambridge University Press, UK and New York USA.

[63] García-Ruiz R, Baggs E (2007) ${ }^{15} \mathrm{~N}-\mathrm{N}_{2} \mathrm{O}$ emissions from decomposition of plant residues in olive oil orchard. En: Towards a better efficiency in N use, pp. 250-253.

[64] Baggs EM, Stevenson M, Pihlatie M, Regar A, Cook H, Cadisch G (2003) Nitrous oxide emissions following application of residues and fertiliser under zero and conventional tillage. Plant Soil. 254: 361.

[65] Baggs EM, Rees RM, Smith KA, Vinten AJA (2000) Nitrous oxide emission from soils after incorporating crop residues. Soil Use Manage. 16: 82-87.

[66] Duiker SW, Lal R (2000) Carbon budget study using $\mathrm{CO}_{2}$ flux measurements from a no till system in central Ohio. Soil Till. Res. 54: 21-30.

[67] Adiku SGK, Narh S, Jones JW, Laryea KB, Dowuona GN (2008) Short-term effects of crop rotation, residue management, and soil water on carbon mineralization in a tropical cropping system. Plant Soil, 311: 29-38.

[68] Manzoni S, Proporato A (2009) Soil carbon and nitrogen mineralization: Theory and models across scales. Soil Biol. Biochem. 41, 1355-1379.

[69] Cleveland CC, Liptzin D (2007) C:N: P stoichiometry in soil: is there a "Redfield ratio" for the microbial biomass? Biogeochemistry. 85: 235-252.

[70] Jensen LS, Mueller T, Magid J, Nielsen NE (1997) Temporal variation of C and N mineralization, microbial biomass and extractable organic pools in soil after oilseed rape straw incorporation in the field. Soil Biol. Biochem. 29: 1043-1055.

[71] Bernal MP, Sánchez-Monedero MA, Paredes C, Roig A (1998) Carbon mineralization from organic wastes at different composting stages during their incubation with soil. Agr. Ecosyst. Environ. 69: 175-189. 
[72] Hollis JM, Jones RJA, Palmer RC (1977) The effect of organic matter and particle size on the water retention properties of some soils in the West Midlands of England. Geoderma. 17, 225- 238.

[73] López-Piñeiro A, Albarrán A, Nunes JM, Barreto C (2008) Short and medium-term effects of two-phase olive mill waste application on olive grove production and soil properties under semiarid Mediterranean conditions. Bioresource Technol. 99: 79827987.

[74] Piotrowska A, Iamarino G, Rao MA, Gianfred L (2006) Short-term effects of olive mill waste water (OMW) on chemical and biochemical properties of a semiarid Mediterranean soil. Soil Biol. Biochem. 38: 600-610.

[75] Montemurro F, Convertini G, Ferri D (2004) Mill wastewater and olive pomace compost as amendments for rye-grass. Agronomie. 24, 481-486.

[76] Benítez C, Tejada M, González JL (2003) Kinetics of mineralization of nitrogen in a pig slurry compost applied to soils. Compost Sci. Util. 11: 72-80.

[77] Dick RP (1994) Influence of long-term tillage and crop rotation combinations on soil enzyme activities. Soil Sci. Soc. Am. J. 56: 783-788.

[78] Mäder P, Fliessbacth A, Dubois D, Gunst L, Fried P, Niggli U (2002) Soil fertility and biodiversity in organic farming. Science. 296: 1694-1697.

[79] Melero S, Porras JC, Herencia JF, Madejón E (2006) Chemical and biochemical properties in a silty loam soil under conventional and organic management. Soil Till. Res. 90: 162-170. 